\title{
Determination of aroma and volatile flavor compounds and sensory properties of set-type yoghurts enriched with immature wheat grain
}

\author{
Çiğdem Konak Göktepe ${ }^{1}$, Nihat Akın²
}

1 - Karapınar Aydoğanlar Vocational School, Selcuk University, Konya, Turkey

2 - Selcuk University, Konya, Turkey

Keywords:

Yoghurt

İmmature wheat

Aroma

Sensory

Article history:

Received 28.03.2020

Received in revised

form 15.05.2020

Accepted 30.06.2020

\section{Corresponding} author:

Çiğdem Konak

Göktepe

E-mail:

ckonak@selcuk.edu.tr

DOI: $10.24263 / 2310-$

1008-2020-8-1-4

\section{Abstract}

Introduction. The aim of this study was to investigate how enriching yoghurt with immature wheat grain (IWG) influence on aroma and volatile compounds and sensory properties of yoghurts.

Materials and methods. IWG was harvested in two different stages called the milky and dough stage before fully maturation phase. Yoghurt samples were enriched with milky stage grain flour (MSF) and dough stage grain flour (DSF) at different levels $(0,1,2$, and $3 \%)$ to benefit from their prebiotic and functional properties. The flavor and volatile compound contents of the yoghurt samples were identified by using the solid-phase microextraction (SPME) technique on the 1st, 14th and 28th days of the storage period.

Results and discussion. The amount of acetaldehyde, the characteristic flavoring agent of yoghurt, was at a higher concentration in the yoghurt enriched with MSF. Also, acetaldehyde decreased from 14.87 to $7.54 \mathrm{ppm}$ in the samples as the storage period progressed. An increase in the amount of ethyl alcohol was observed in the control and other enriched yoghurt samples in accordance with the decrease in the amount of acetaldehyde with storage. Besides, volatile acids that contributed to taste and aroma such as butyric acid, octanoic acid, acetic acid and hexanoic acid were identified in the enriched yoghurt samples. Isobutyl 2-methylvalerate, which caused cereal-like taste and smell, was determined in yoghurt samples enriched with MSF and DSF. This ester increased depending on the enrichment ratios and it led to intense cereallike taste in yoghurts with enrichment ratio of $3 \%$. As the ratio of addition to yoghurt samples enriched with IWG flour increased, the cereal flavor became predominant and this reduced consumer appreciation.

Conclusions. Using IWG flour in yoghurt production effected on aroma and volatile flavor compounds of yoghurt samples. In this context, flavoring agents can be used to mask the cereal flavor and taste that becomes dominant by increasing concentration of MSF and DSF in yoghurts. 


\section{Introduction}

Yoghurt has long been among the most recognized and consumed products of fermented milk products. It is produced by lactic acid fermentation using Streptococcus thermophilus and Lactobacillus delbrueckii ssp. bulgaricus. More than 90 different aroma and volatile flavor compounds have been identified in yoghurt and the formation of these aromatic compounds is impressed by the milk composition, yoghurt processing condition, yoghurt starter cultures, and incubation conditions [1].

As well as lactic acid with an acidic and refreshing taste, various carbonyl compounds such as acetone, diacetyl, and acetaldehyde are the main compounds that give the yoghurt its typical taste and aroma. Among these compounds, acetaldehyde is considered as the most important characteristic flavor compound of yoghurt [2,3]. Several compounds including non-volatile acids (lactic, pyruvic, oxalic or succinic acids) consisting of lactose, caseins, amino acids, lipids, citric acid, and free fatty acids, volatile acids (butyric, acetic, formic or propionic acid), carbonyl compounds (acetaldehyde, acetone, diacetyl or acetoin) and amino acids also form flavor compounds in yoghurt [4]. Since yoghurt bacteria lack the alcohol dehydrogenase enzyme required for the conversion of acetaldehyde to ethanol, acetaldehyde compounds are present in yoghurt in high concentrations (in the range of 5-21 mg/l) compared to other compounds [5].

In 2020 years, there has been an increase in demand for functional foods in conjunction with low-calorie, low-fat and low-cholesterol foods. An important development regarding this issue has been in foods enriched with dietary fiber [6]. In this context, IWG containing high dietary fiber (especially fructooligosaccharides), protein, and antioxidant components was used in recent studies as a prebiotic, improving textural properties and nutritional value of food product $[7,8]$. IWG was harvested at 2-3 weeks after anthesis, this physiological stage called the 'milky phase'. In the milky phase, wheat grain has maximum fructooligosaccharides content and antioxidant compounds, thereafter their concentration rapidly reduces per grain $[7,9]$.

The flavor and aroma of yoghurt play an important role in the consumption of it. Therefore some researchers investigated the effect of various additives used fortification of yoghurt to improve textural, nutritional, and sensorial attributes on aroma compounds of yoghurts $[10,11]$. These authors stated that of all the additives studied, starch, pectin, and some sweeteners presented a significant effect on the aroma compounds of yoghurt.

In this study, the aroma and volatile compound contents of the yoghurt samples enriched with MSF and DSF were determined and their effects on their sensory properties were investigated. For this purpose, the solid-phase microextraction technique (SPME) was used to define the aroma and volatile profiles of the yoghurt samples enriched IWG by using gas chromatography-mass spectrometry (GC-MS).

\section{Materials and methods}

\section{Materials}

Whole-fat raw milk $(12.44 \pm 0.08 \%$ total dry matter, $3.85 \pm 0.08 \%$ protein, $0.76 \pm 0.11 \%$ ash, $4.00 \pm 0.14 \%$ fat, $\mathrm{pH}$ : $6.74 \pm 0.01)$ used in yoghurt production was taken from the dairy farm of the Faculty of Agriculture at Selcuk University. Total non-fat milk solids of the milk were standardized to $12 \%$ with medium-heated skim milk powder (ENKA Dairy Product, Turkey). Yoghurt starter cultures (Streptococcus thermophilus and Lactobacillus delbrueckii 
subsp. bulgaricus) and K-carrageenan were obtained from Chr. Hansen-Peyma (Istanbul, Turkey) and Sigma-Aldrich Chemical Company (St. Louis, MO, USA), respectively.

IWG was obtained from the 'Soylu Durum Wheat' which harvested from the Saricalar Research and Application Farm of the Faculty of Agriculture at Selcuk University in two different maturing stages called milky (65\% moisture in grain) and dough stage (50\% moisture in grain).

\section{Production of whole wheat flour from immature wheat grain}

After the harvest, wheat grains were separated from their stems and husks. The cleaned wheat was milled in a laboratory type hammer mill equipped with a $1 \mathrm{~mm}$ opening screen (Falling Number-3100 Laboratory Mill, Perten Instruments AB, Huddinge, Sweden) to produce IWG flour.

\section{Production of yoghurt samples}

After non-fat solids of raw milk were standardized to $12 \%(\mathrm{w} / \mathrm{w})$ with the medium-heated skim milk powder, it was portioned in equal amounts and put into containers. Standardized milk was enriched with the MSF and DSF at levels of 0 (control), 1, 2, or 3\% (w/v). $0.03 \%$ $\mathrm{K}$-carrageenan was added to prevent sedimentation of the MSF and DSF into the yoghurt samples and mixed with Ultra-Turrax blender until it became homogeneous. The obtained mixture, which was subjected to heat treatment at $90{ }^{\circ} \mathrm{C}$ for 10 minutes by stirring, was cooled to approximately $45 \pm 1{ }^{\circ} \mathrm{C}$. After cooling, the mixture was inoculated with $3 \%(\mathrm{v} / \mathrm{v})$ yoghurt starter cultures and incubated until $\mathrm{pH} 4.6$ at $43 \pm 1{ }^{\circ} \mathrm{C}$. At the end of incubation, yoghurt samples were cooled to $+4{ }^{\circ} \mathrm{C}$ and stored for 28 days under refrigerator conditions.

\section{Method}

\section{Determination of flavor and volatile compounds}

The aroma and volatile compounds in the samples were identified according to the method of Lee, Diono [12] by using gas chromatography and mass spectrometry (GC-MS, model GC 7890 A, Agillent, USA). For this purpose, $3 \mathrm{~g}$ sample was put into $20 \mathrm{ml}$ vials and $3 \mathrm{ml} \mathrm{NaCl}$ solution $(10 \%, \mathrm{w} / \mathrm{v})$ and $10 \mu \mathrm{l}$ of internal standard (IS, $81 \mathrm{ppb} ; 2$ methyl-3 heptanone and 2-methyl pentanoic acid in methanol) were added on it. Samples were mixed at $50{ }^{\circ} \mathrm{C}$ for $30 \mathrm{~min}$ in a heat stirrer. The extraction of volatile compounds was carried out with SPME, a solvent-free extraction technique. It was exposed to headspace conditions at $50{ }^{\circ} \mathrm{C}$ for 30 minutes for the absorption of the aroma compounds of $75 \mu \mathrm{m}$ carboxen / polydimethyl siloxane fiber (CAR / PDMS, Supelco, PA, USA). At the end of this period, it was injected into the GC-MS. After the injection, the fiber was kept in the detector for 3 mins, at $250{ }^{\circ} \mathrm{C}$. The analysis was carried out in splitless mode. The aroma materials were separated using DB-Wax column $(30 \mathrm{~m} \times 0.25 \mathrm{~mm}$ x $0.25 \mu \mathrm{m})$. Helium with a flow rate of 3 $\mathrm{ml} / \mathrm{min}$ was used as the carrier gas. The oven temperature program was started with a $10 \mathrm{~min}$ wait at $50{ }^{\circ} \mathrm{C}$. The oven temperature was gradually raised to $110{ }^{\circ} \mathrm{C}$ with an increase of $5{ }^{\circ} \mathrm{C}$ per minute. Then, it was raised to $250{ }^{\circ} \mathrm{C}$ with an increase of $10{ }^{\circ} \mathrm{C}$ per minute and waited for 10 minutes. Volatile compounds were identified by using the Wiley and NIST flavor libraries in GS/MS. Relative quantities of volatile compounds were calculated by proportioning the peak areas of the internal standard and the peak areas of the volatile compounds. 


\section{Sensory analysis}

Yoghurt samples enriched with MSF and DSF were stored at $+4{ }^{\circ} \mathrm{C}$ for 28 days and sensory analyzes were performed on the 7th and 21st days of storage. The panelist group of 9 people, who carried out the sensory evaluations, consists of academicians between the ages of 30-50 who are working at the Food Engineering Department of Selcuk University. The sensory properties of yoghurt samples were evaluated in terms of appearance, texture, mouth feel, smell, and taste by using a scale of 1 to 5 (1: extremely dislike; 5: extremely like) [13].

\section{Statistical analysis}

Sensory evaluation results were evaluated statistically (ANOVA) in terms of mean and variance analysis and comparisons were made according to the Tukey test at the level of $\mathrm{p}<0.05$ using the MiniTab 7.1 statistics program [14].

\section{Results and discussion}

\section{The aroma and volatile compound content}

The relative amounts of the aroma and volatile compounds of immature wheat flour used to enrich yoghurt are given in Table 1. Flavors and volatile compounds in 7 different groups such as carboxylic acids (4), ketones (8), esters (9), aldehydes (8), hydrocarbons (2), alcohols (9) and, terpenes (2) were identified in the flour obtained from the wheat harvested in milky stage and dough stage.

16 different flavors and volatile compounds were identified in yoghurt samples enriched with MSF and DSF. These compounds belong to different chemical groups such as carboxylic acids (4), aldehydes (1), esters (1), alcohols (3), hydrocarbon (1), and ketones (6).

\section{Carboxylic acids}

4 different volatile acids including butyric acid (butanoic acid) octanoic acid (caprylic acid), acetic acid, and hexanoic acid (capric acid) were identified in the yoghurt samples enriched with MSF and DSF (Table 2).

The concentrations of butyric acid, octanoic acid (caprylic acid), acetic acid and hexanoic acid (capric acid) in the samples ranged between $9.95-24.23 \mathrm{ppm}, 20.18-68.76 \mathrm{ppm}, 15.53$ $34.96 \mathrm{ppm}$ and $23.53-79.25 \mathrm{ppm}$, respectively. The amounts of these short-chain fatty acids increased during the storage period. This could be explained by the high metabolic activity of $L$. delbrueckii ssp. bulgaricus during the storage period, which may lead to increased amounts of these compounds. Terpou, Bekatorou [15] indicated similar results for probiotic yoghurts enriched with wheat bran, that's the amount of short-chain fatty acids increased as the storage period progressed.

In general, it was observed that butyric acid concentrations in yoghurt samples enriched with MSF and DSF increased depending on the enrichment ratio and storage period. However, in some studies, it was stated that enrichment in prebiotic and fiber added yoghurts did not affect butyric acid production [16, 17]. Additionally, free butyric acid, which is found in fermented milk products more than milk, causes rancid taste as well as cheese taste and aroma [18].

When the concentration of acetic acid of the yoghurt samples was analyzed, it could be stated that they did not show a regular increase or decrease depending on the enrichment material, the enrichment ratio, and the storage period. 
Table 1

Identification of aroma and volatile compounds (ppm) of MSF and DSF

\begin{tabular}{|c|c|c|c|c|c|}
\hline Compound name & MSF $^{1}$ & DSF $^{2}$ & Compound name & MSF $^{1}$ & DSF $^{2}$ \\
\hline Carboxylic acids & & & Aldehydes & & \\
\hline Hexanoic acid & 1.91 & 3.69 & trans-2-Heptenal & 0.41 & 1.00 \\
\hline Isovaleric acid & 3.32 & ND & Nonanal & 0.43 & 10.41 \\
\hline Octanoic acid & 0.21 & ND & Octanal & ND & 3.85 \\
\hline $\begin{array}{l}\text { 2- Methylheptanoic } \\
\text { acid }\end{array}$ & 1.13 & ND & n-decanal & ND & 1.91 \\
\hline Ketones & & & Benzaldehyde & ND & 3.53 \\
\hline 3,5-octadiene-2-one & ND & 3.73 & trans-2-Nonenal & ND & 0.57 \\
\hline 3-octanone & ND & 0.32 & 2-Butyl-2-octenal & ND & 0.88 \\
\hline 2-undecanone & ND & 0.29 & Furfural & ND & 0.38 \\
\hline 2-octanone & ND & 1.00 & Hydrocarbons & & \\
\hline 2-nonanone & 3.16 & 23.66 & Styrene & 5.56 & 4.40 \\
\hline $\begin{array}{l}\text { 6-Methyl-5-hepten-2- } \\
\text { one }\end{array}$ & 7.83 & 0.95 & n-Dodecane & ND & 1.09 \\
\hline $\begin{array}{l}\text { 4-(3'-Thienyl)-1,5- } \\
\text { dihydro-2H-pyrrol-5- } \\
\text { one }\end{array}$ & 7.20 & ND & Alcohols & & \\
\hline Esters & & & Nonanol & 2.18 & 0.38 \\
\hline Hexyl hexanoate & ND & 0.47 & 1-Tetradecanol & 1.06 & 0.06 \\
\hline Methyl heptacosanoate & ND & 1.24 & 2-Heptanol & 2.11 & 0.68 \\
\hline Butyl hexanoate & ND & 0.65 & 1-Hexanol & 0.35 & 3.89 \\
\hline Methyl myristate & 0.39 & ND & Benzyl alcohol & 3.37 & 2.24 \\
\hline Methyl nonanoate & 4.43 & 3.02 & Phenethyl alcohol & 0.39 & \\
\hline $\begin{array}{l}\text { 2-Propenoic acid, 3- } \\
\text { ethoxy-, ethyl ester }\end{array}$ & 1.93 & 2.83 & 3-Pentanol & ND & 2.38 \\
\hline Methyl hexanoate & 9.61 & 3.83 & 1-octen-3-ol & ND & 2.99 \\
\hline $\begin{array}{l}\text { Propanoic acid, 2- } \\
\text { methyl-, 2,2-dimethyl- } \\
\text { 1-(2-hydroxy-1- } \\
\text { methylethyl) propyl } \\
\text { ester }\end{array}$ & 1.16 & ND & 3,5-Octadien-2-ol & ND & 1.78 \\
\hline \multirow[t]{3}{*}{ Ethyl acetate } & 0.59 & ND & Terpenes & & \\
\hline & & & Limonene & 1.54 & 2.43 \\
\hline & & & Eucalyptol & 1.50 & ND \\
\hline
\end{tabular}

1MSF: whole meal obtained from wheat harvested at milky development stage; DSF: whole meal obtained from wheat harvested at milky development stage; ND: not detected 
Table 2

Concentration of carboxylic acids and esters (ppm) of enriched yoghurt samples with MSF and DSF during storage period

\begin{tabular}{|c|c|c|c|c|c|c|c|c|}
\hline & $\begin{array}{c}\text { Period of } \\
\text { storage } \\
\text { (days) }\end{array}$ & $\begin{array}{l}\text { Cont } \\
\text { rol } \\
\end{array}$ & $\begin{array}{l}1 \% \\
\text { MSF }\end{array}$ & $\begin{array}{c}2 \% \\
\text { MSF }\end{array}$ & $\begin{array}{l}3 \% \\
\text { MSF }\end{array}$ & $\begin{array}{c}1 \% \\
\text { DSF }\end{array}$ & $\begin{array}{l}2 \% \\
\text { DSF }\end{array}$ & $\begin{array}{l}\text { 3\% } \\
\text { DSF }\end{array}$ \\
\hline \multicolumn{9}{|l|}{$\begin{array}{l}\text { Carboxylic } \\
\text { acids }\end{array}$} \\
\hline \multirow{3}{*}{$\begin{array}{l}\text { Butyric acid } \\
\text { (Butanoic } \\
\text { acid) }\end{array}$} & 1 & $\begin{array}{r}17.48 \\
\pm 1.82 \\
\end{array}$ & ND & $\begin{array}{r}15.59 \\
\pm 1.38 \\
\end{array}$ & $\begin{array}{r}21.19 \\
\pm 1.29\end{array}$ & $\begin{array}{c}9.95 \\
\pm 0.49 \\
\end{array}$ & $\begin{array}{r}12.45 \\
\pm 1.30 \\
\end{array}$ & ND \\
\hline & 14 & $\begin{array}{l}20.76 \\
\pm 0.96\end{array}$ & $\begin{array}{l}11.79 \\
\pm 2.00\end{array}$ & $\begin{array}{l}17.60 \\
\pm 0.44\end{array}$ & ND & $\mathrm{ND}$ & $\begin{array}{r}16.98 \\
\pm 1.91\end{array}$ & $\begin{array}{l}24.23 \\
\pm 0.56\end{array}$ \\
\hline & 28 & $\mathrm{ND}$ & $\begin{array}{l}18.17 \\
\pm 0.94\end{array}$ & $\begin{array}{r}19.92 \\
\pm 1.13\end{array}$ & ND & $\begin{array}{r}19.59 \\
\pm 1.53\end{array}$ & $\begin{array}{r}19.23 \\
\pm 1.21\end{array}$ & ND \\
\hline \multirow{3}{*}{ Octanoic acid } & 1 & $\begin{array}{r}49.82 \\
\pm 3.94 \\
\end{array}$ & $\begin{array}{r}39.89 \\
\pm 5.62 \\
\end{array}$ & ND & $\begin{array}{r}43.33 \\
\pm 4.56 \\
\end{array}$ & $\mathrm{ND}$ & $\begin{array}{l}20.18 \\
\pm 0.47\end{array}$ & ND \\
\hline & 14 & $\begin{array}{l}46.11 \\
\pm 5.11 \\
\end{array}$ & $\begin{array}{r}38.56 \\
\pm 3.09 \\
\end{array}$ & ND & $\begin{array}{r}56.30 \\
\pm 2.17 \\
\end{array}$ & $\begin{array}{r}46.98 \\
\pm 4.47\end{array}$ & $\begin{array}{r}43.35 \\
\pm 6.12 \\
\end{array}$ & $\begin{array}{l}47.17 \\
\pm 3.74 \\
\end{array}$ \\
\hline & 28 & $\begin{array}{l}56.66 \\
\pm 7.97\end{array}$ & $\begin{array}{l}53.37 \\
\pm 5.96\end{array}$ & $\begin{array}{l}52.49 \\
\pm 6.83 \\
\end{array}$ & $\begin{array}{l}68.76 \\
\pm 6.02\end{array}$ & $\begin{array}{l}54.26 \\
\pm 2.90\end{array}$ & $\begin{array}{l}51.72 \\
\pm 5.84\end{array}$ & $\begin{array}{l}48.78 \\
\pm 1.95\end{array}$ \\
\hline \multirow{3}{*}{ Acetic acid } & 1 & $\begin{array}{r}28.85 \\
\pm 9.35 \\
\end{array}$ & $\begin{array}{r}25.31 \\
\pm 3.80 \\
\end{array}$ & $\begin{array}{r}23.59 \\
\pm 1.80 \\
\end{array}$ & $\begin{array}{r}28.62 \\
\pm 5.73 \\
\end{array}$ & $\begin{array}{r}16.48 \\
+3.78 \\
\end{array}$ & $\begin{array}{r}15.53 \\
\pm 6.33 \\
\end{array}$ & $\begin{array}{r}18.95 \\
\pm 3.93 \\
\end{array}$ \\
\hline & 14 & $\begin{array}{l}24.95 \\
\pm 0.62\end{array}$ & $\begin{array}{l}19.89 \\
\pm 0.38\end{array}$ & $\begin{array}{l}33.86 \\
\pm 1.80\end{array}$ & $\begin{array}{l}32.58 \\
\pm 8.19\end{array}$ & $\begin{array}{l}25.09 \\
\pm 6.26\end{array}$ & $\begin{array}{l}28.67 \\
\pm 7.06\end{array}$ & $\begin{array}{l}34.96 \\
\pm 6.46\end{array}$ \\
\hline & 28 & $\begin{array}{r}27.75 \\
\pm 3.30\end{array}$ & $\begin{array}{l}40.58 \\
\pm 9.53\end{array}$ & $\begin{array}{r}29.28 \\
\pm 3.66\end{array}$ & $\begin{array}{l}31.76 \\
\pm 6.10\end{array}$ & $\begin{array}{l}28.54 \\
\pm 0.14\end{array}$ & $\begin{array}{l}27.70 \\
\pm 5.31\end{array}$ & $\begin{array}{l}22.57 \\
\pm 1.87\end{array}$ \\
\hline \multirow{3}{*}{ Hexanoic acid } & 1 & ND & ND & $\begin{array}{r}23.53 \\
\pm 1.17 \\
\end{array}$ & $\begin{array}{r}31.26 \\
\pm 2.77\end{array}$ & $\begin{array}{r}25.60 \\
\pm 0.23 \\
\end{array}$ & $\begin{array}{r}64.03 \\
\pm 1.66 \\
\end{array}$ & $\begin{array}{l}56.38 \\
\pm 8.45 \\
\end{array}$ \\
\hline & 14 & $\begin{array}{r}45.19 \\
\pm 1.82 \\
\end{array}$ & $\begin{array}{r}53.59 \\
\pm 3.00 \\
\end{array}$ & ND & $\begin{array}{r}57.02 \\
\pm 2.81 \\
\end{array}$ & $\begin{array}{r}52.25 \\
\pm 1.11 \\
\end{array}$ & $\begin{array}{r}59.02 \\
\pm 6.68\end{array}$ & $\begin{array}{l}79.25 \\
\pm 8.62\end{array}$ \\
\hline & 28 & $\begin{array}{r}55.00 \\
\pm 2.83 \\
\end{array}$ & $\begin{array}{l}56.91 \\
\pm 1.62 \\
\end{array}$ & $\begin{array}{r}47.22 \\
\pm 3.93 \\
\end{array}$ & ND & $\begin{array}{r}67.32 \\
\pm 3.39 \\
\end{array}$ & $\begin{array}{r}64.65 \\
\pm 3.98 \\
\end{array}$ & $\begin{array}{l}56.32 \\
\pm 3.17 \\
\end{array}$ \\
\hline \multicolumn{9}{|l|}{ Esters } \\
\hline \multirow{3}{*}{$\begin{array}{l}\text { Isobutyl 2- } \\
\text { methylvalerat } \\
\text { e }\end{array}$} & 1 & ND & ND & ND & ND & ND & $\begin{array}{l}13.63 \\
\pm 0.51\end{array}$ & $\begin{array}{l}20.31 \\
\pm 0.55\end{array}$ \\
\hline & 14 & ND & $\begin{array}{l}22.24 \\
\pm 0.66\end{array}$ & ND & $\begin{array}{l}12.42 \\
\pm 0.42\end{array}$ & $\begin{array}{l}14.89 \\
\pm 0.77\end{array}$ & $\begin{array}{r}20.96 \\
\pm 0.42\end{array}$ & ND \\
\hline & 28 & ND & $\begin{array}{l}17.78 \\
\pm 0.63 \\
\end{array}$ & ND & ND & ND & $\begin{array}{l}30.38 \\
\pm 0.72 \\
\end{array}$ & ND \\
\hline
\end{tabular}

${ }^{1}$ MSF: whole meal obtained from wheat harvested at milky development stage; ${ }^{2}$ DSF: whole meal obtained from wheat harvested at milky development stage; ND: not detected 


\section{Esters}

During the 28 days of storage, one ester, an isobutyl 2-methylvalerate in amounts ranging from $12.42 \mathrm{ppm}$ to $30.38 \mathrm{ppm}$, was identified in the yoghurt samples. The isobutyl 2methylvalerate was not found in the control yoghurts without enrichment MSF and DSF, but only in the yoghurts containing MSF and DSF. Thus, it could be stated that this ester causes the cereal-like taste and aroma in the enriched yoghurt samples. Similarly, Terpou, Bekatorou [15] identified high amounts of five different esters in yoghurts fortified with wheat bran and reported that these esters gave cereal flavor to yoghurts. In addition to these, in another study, Terpou, Gialleli [18] reported that esters such as ethyl butanoate, ethyl hexanoate, ethyl octanoate, and ethyl decanoate were important esters identified in all sour milk was produced by using wheat bran supported probiotic biocatalysts. Esters generally are responsible for the fruit odor in food products. In addition, esters are known to reduce the effects of unpleasant odor from phenolic compounds and short-chain fatty acids [19].

\section{Aldehydes}

The concentrations of acetaldehyde, which is the characteristic flavoring agent of yoghurt, varied between $14.87 \mathrm{ppm}$ and $1.27 \mathrm{ppm}$ during the storage period in yoghurt samples (Table 3). As seen in Table 3, the acetaldehyde level of yoghurts enriched with MSF was higher than those enriched with DSF. This could be explained by the fact that MSF including high fructooligosaccharides further supports the activity of yoghurt bacteria. While the amount of fructooligosaccharide that is prebiotic in the wheat grain during maturing of wheat increases rapidly until the 10th day after flowering, it decreases rapidly in the latter days of the next maturing stages [20,21]. In this context, the MSF additive harvested on the 20th day after flowering supported the development of yoghurt bacteria more than the DSF additive harvested on the 30th day after flowering. In 1\% MSF, 2\% MSF, and 3\% MSF samples, the acetaldehyde was determined as 9.66, 6.28, and $5.27 \mathrm{ppm}$, respectively, on the first day of the storage period. As seen from the results, the amount of acetaldehyde decreased in yoghurt samples as the enrichment ratio increased. The cereal-like taste and aroma became dominant in the samples as the concentrations of MSF and DSF added to enrich the yoghurt samples increased. Besides, some aroma compounds such as esters identified in enriched yoghurts can mask acetaldehyde, which is the characteristic aroma of yoghurt.

The concentration of acetaldehyde was determined as $14.78,12.18$, and $7.54 \mathrm{ppm}$ in control yoghurt on the 1st, 14th, and 28th days of storage, respectively. The acetaldehyde levels showed a decrease in all samples depending on the progressive storage time (Table 3 ). This decrease in the concentration of acetaldehyde could be explained by the reduction of acetaldehyde to ethyl alcohol [22]. In addition, it could be said that the decrease in acetaldehyde level in yoghurts during storage might be due to evaporation of acetaldehyde from samples and/or hydrolysis by microbial enzymes to form different substances. Acetaldehyde can easily oxidize to acetate and accordingly, its level decreases. Since the said condition occurs at high acidity values, it is stated that the loss of acetaldehyde occurring in the later stages of storage is caused by the enzyme alcohol dehydrogenase originated from $S$. thermophilus. [4, 23, 24]. Our result is similar to the studies performed with plain yoghurt samples [25, 26] or the yoghurt samples enriched with different additives [27, 28]. 
Table 3

Concentration of aldehydes, alchols and hydrocarbons (ppm) of enriched yoghurt samples with MSF and DSF during storage period

\begin{tabular}{|c|c|c|c|c|c|c|c|c|}
\hline & $\begin{array}{c}\text { Period } \\
\text { of } \\
\text { storage } \\
\text { (days) }\end{array}$ & Control & $\begin{array}{c}1 \% \\
\text { MSF }\end{array}$ & $\begin{array}{c}2 \% \\
\text { MSF }\end{array}$ & $\begin{array}{c}3 \% \\
\text { MSF }\end{array}$ & $\begin{array}{c}1 \% \\
\text { DSF }\end{array}$ & $\begin{array}{l}2 \% \\
\text { DSF }\end{array}$ & $\begin{array}{l}3 \% \\
\text { DSF }\end{array}$ \\
\hline \multicolumn{9}{|l|}{ Aldehydes } \\
\hline \multirow{3}{*}{ Acetaldehyde } & 1 & $\begin{array}{l}14.87 \\
\pm 1.02 \\
\end{array}$ & $\begin{array}{r}10.35 \\
\pm 0.84 \\
\end{array}$ & $\begin{array}{l}9.66 \\
\pm 0.78 \\
\end{array}$ & $\begin{array}{l}6.28 \\
\pm 1.14 \\
\end{array}$ & $\begin{array}{l}5.27 \\
\pm 0.71 \\
\end{array}$ & $\begin{array}{l}2.81 \\
\pm 1.20 \\
\end{array}$ & $\begin{array}{l}1.27 \\
\pm 0.11 \\
\end{array}$ \\
\hline & 14 & $\begin{array}{l}12.18 \pm \\
0.62\end{array}$ & $\begin{array}{l}7.66 \\
\pm 1.15\end{array}$ & $\begin{array}{l}7.53 \\
\pm 0.42\end{array}$ & $\begin{array}{l}4.36 \\
\pm 0.83\end{array}$ & $\begin{array}{l}4.10 \\
\pm 0.54\end{array}$ & $\begin{array}{l}2.88 \pm \\
0.97\end{array}$ & $\begin{array}{l}2.75 \\
\pm 0.19 \\
\end{array}$ \\
\hline & 28 & $\begin{array}{l}7.54 \\
\pm 0.101 \\
\end{array}$ & $\begin{array}{l}5.78 \\
\pm 0.28 \\
\end{array}$ & $\begin{array}{l}4.76 \\
\pm 0.48 \\
\end{array}$ & $\begin{array}{l}4.37 \\
\pm 0.49 \\
\end{array}$ & $\begin{array}{l}3.82 \\
\pm 0.41 \\
\end{array}$ & $\begin{array}{l}1.71 \\
\pm 0.78 \\
\end{array}$ & $\begin{array}{l}1.44 \\
\pm 0.16 \\
\end{array}$ \\
\hline \multicolumn{9}{|l|}{ Alcohols } \\
\hline \multirow{3}{*}{ Ethanol } & 1 & $\begin{array}{l}2.12 \\
\pm 0.19\end{array}$ & $\begin{array}{l}3.76 \\
\pm 0.62\end{array}$ & $\begin{array}{l}5.56 \pm \\
0.35\end{array}$ & $\begin{array}{l}2.58 \pm \\
0.69\end{array}$ & $\begin{array}{l}4.33 \pm \\
0.31\end{array}$ & $\begin{array}{l}6.10 \pm \\
0.79\end{array}$ & $\begin{array}{l}1.64 \\
\pm 0.31\end{array}$ \\
\hline & 14 & $\begin{array}{l}3.73 \\
\pm 0.59\end{array}$ & $\begin{array}{l}4.11 \\
\pm 1.08 \\
\end{array}$ & $\begin{array}{l}6.42 \\
\pm 0.65 \\
\end{array}$ & $\begin{array}{l}2.24 \\
\pm 0.52 \\
\end{array}$ & $\begin{array}{l}2.94 \\
\pm 0.79\end{array}$ & $\begin{array}{l}7.46 \\
\pm 1.03 \\
\end{array}$ & $\begin{array}{l}7.77 \\
\pm 0.63 \\
\end{array}$ \\
\hline & 28 & $\begin{array}{l}5.38 \\
\pm 0.85\end{array}$ & $\begin{array}{l}6.26 \\
\pm 1.06\end{array}$ & $\begin{array}{l}5.81 \\
\pm 1.29\end{array}$ & $\begin{array}{l}3.55 \\
\pm 0.46\end{array}$ & $\begin{array}{l}3.27 \\
\pm 0.39\end{array}$ & $\begin{array}{l}8.03 \\
\pm 0.77\end{array}$ & $\begin{array}{l}8.77 \\
\pm 0.41 \\
\end{array}$ \\
\hline \multirow{3}{*}{ 1,2-Butanediol } & 1 & ND & ND & ND & $\begin{array}{l}6.97 \pm \\
0.60\end{array}$ & ND & ND & ND \\
\hline & 14 & ND & ND & ND & ND & ND & ND & ND \\
\hline & 28 & $\begin{array}{l}4.95 \\
\pm 0.26\end{array}$ & ND & ND & $\begin{array}{l}3.96 \\
\pm 0.43\end{array}$ & $\begin{array}{l}3.45 \\
\pm 0.56\end{array}$ & $\begin{array}{l}2.95 \\
\pm 0.23\end{array}$ & \\
\hline \multirow{3}{*}{$\begin{array}{l}\text { Furfuryl } \\
\text { alcohol }\end{array}$} & 1 & ND & $\begin{array}{l}15.62 \\
\pm 0.67\end{array}$ & $\begin{array}{l}3.80 \\
\pm 0.37\end{array}$ & ND & ND & ND & ND \\
\hline & 14 & ND & ND & $\begin{array}{l}8.06 \\
\pm 0.63 \\
\end{array}$ & $\begin{array}{l}3.70 \\
\pm 0.45\end{array}$ & ND & ND & $\begin{array}{l}8.67 \\
\pm 0.47 \\
\end{array}$ \\
\hline & 28 & $\begin{array}{l}7.01 \\
\pm 0.98\end{array}$ & $\begin{array}{l}7.88 \\
\pm 0.95\end{array}$ & $\begin{array}{l}9.86 \\
\pm 0.57\end{array}$ & ND & ND & ND & $\begin{array}{r}12.68 \\
\pm 0.96 \\
\end{array}$ \\
\hline \multicolumn{9}{|l|}{ Hydrocarbons } \\
\hline \multirow{3}{*}{ Styrene } & 1 & $\begin{array}{l}4.65 \\
\pm 0.27 \\
\end{array}$ & ND & ND & $\begin{array}{l}2.53 \\
\pm 0.29 \\
\end{array}$ & ND & ND & ND \\
\hline & 14 & ND & ND & ND & ND & ND & ND & ND \\
\hline & 28 & $\begin{array}{l}23.31 \\
\pm 1.03\end{array}$ & ND & ND & $\begin{array}{l}26.36 \\
\pm 0.43\end{array}$ & ND & ND & ND \\
\hline
\end{tabular}

${ }^{1}$ MSF: whole meal obtained from wheat harvested at milky development stage; ${ }^{2} \mathrm{DSF}$ : whole meal obtained from wheat harvested at milky development stage; ND: not detected 


\section{Alcohols}

As seen in Table 3, three different types of alcohol, including ethyl alcohol, 1,2butanediol, and furfuryl alcohol were identified in yoghurt samples enriched with MSF and DSF. The amount of ethyl alcohol varied between 1.64 and 8.77 ppm in yoghurt samples.

An increase in the concentration of ethyl alcohol was observed in all samples in accordance with the decrease in the amount of acetaldehyde depending on the storage period. Besides, the content of ethyl alcohol was higher in enriched yoghurt samples compared to control yoghurts (Table 3). This may be explained by the fact that MSF and DSF additives added to yoghurt support the activity of starter culture [29].

Furfuryl alcohol amounts of enriched yoghurt samples ranged from $3.70 \mathrm{ppm}$ to 15.62 ppm. Furfuryl alcohol consists of lactose, which occurs as a result of heat treatment applied to yoghurt milk [30]. Although a regular increase and decrease in concentration of furfuryl alcohol were not detected during the storage period, it was observed that the furfuryl alcohol content of yoghurts enriched with $2 \%$ MSF increased as the storage period progressed. This increase in furfuryl alcohol level is thought to be due to the activity of yoghurt starter bacteria that continue during storage were best supported by a $2 \%$ MSF additive.

\section{Hydrocarbons}

Styrene, one of the aromatic hydrocarbons, was identified in the control and yoghurt samples enriched with 3\% MSF on the 1st and 28th days of the storage period, while this hydrocarbon was not found in any yoghurt samples on the 14th day of storage. Styrene, which has a sweet taste and can be easily evaporable is usually found in plants, but also in fruits, vegetables, nuts, milk, and dairy products [31]. Our result is in agreement with the findings of Terpou, Gialleli [18] who identified volatile flavor compounds in sour milk produced by using wheat bran supported probiotic biocatalysts. On the other hand, these researchers stated that while the styrene was detected on the first day of storage, were not detected at 30th day and this situation could be caused by metabolizing other compounds.

\section{Ketones}

Six different ketones were identified in the yoghurt samples during the storage. Of these ketones, 2,3-pentanedion and 4-octanone were identified in all yoghurt samples, while 2butanone, 3-hydroxy, 2-nonenone 3-methyl-2-butanone, and 2-dodecanone were not identified in some yoghurt samples throughout the storage (Table 4). It could be said that the identified ketones were caused by heat treatment applied to yoghurt milk. Because ketones are formed by the thermal breakdown of fat caused by heating the yoghurt milk [32]. 
Table 4

Concentration of ketones (ppm) of enriched yoghurt samples with MSF and DSF during storage period

\begin{tabular}{|c|c|c|c|c|c|c|c|c|}
\hline & $\begin{array}{c}\text { Period } \\
\text { of } \\
\text { storage } \\
\text { (days) }\end{array}$ & $\begin{array}{l}\text { Cont } \\
\text { rol }\end{array}$ & $\begin{array}{l}1 \% \\
\text { MSF }\end{array}$ & $\begin{array}{l}2 \% \\
\text { MSF }\end{array}$ & $\begin{array}{l}3 \% \\
\text { MSF }\end{array}$ & $\begin{array}{l}1 \% \\
\text { DSF }\end{array}$ & $\begin{array}{l}2 \% \\
\text { DSF }\end{array}$ & $\begin{array}{l}3 \% \\
\text { DSF }\end{array}$ \\
\hline \multicolumn{9}{|l|}{ Ketones } \\
\hline \multirow{3}{*}{$\begin{array}{l}\text { 2-Butanone, 3- } \\
\text { hydroxy (Acetoin) }\end{array}$} & 1 & $\begin{array}{l}12.43 \\
\pm 1.28\end{array}$ & $\begin{array}{l}10.86 \\
\pm 0.88\end{array}$ & ND & $\begin{array}{l}12.14 \\
\pm 1.43\end{array}$ & ND & $\begin{array}{c}4.43 \pm \\
0.36\end{array}$ & $\begin{array}{c}3.67 \\
\pm 0.35\end{array}$ \\
\hline & 14 & $\begin{array}{c}7.61 \\
\pm 0.70\end{array}$ & $\begin{array}{c}4.03 \pm \\
1.17\end{array}$ & $\begin{array}{c}6.79 \\
\pm 0.52\end{array}$ & $\begin{array}{r}9.16 \\
\pm 0.89\end{array}$ & $\begin{array}{r}10.38 \\
\pm 1.22\end{array}$ & $\begin{array}{c}8.68 \\
\pm 0.45\end{array}$ & $\begin{array}{r}8.87 \\
+3.02 \\
\end{array}$ \\
\hline & 28 & $\begin{array}{c}8.35 \\
\pm 2.04\end{array}$ & $\begin{array}{r}10.94 \\
\pm 2.78\end{array}$ & $\begin{array}{c}7.80 \\
\pm 0.21\end{array}$ & $\begin{array}{c}9.77 \\
\pm 0.46\end{array}$ & $\begin{array}{l}11.71 \\
\pm 1.27\end{array}$ & $\begin{array}{c}6.78 \\
\pm 1.06\end{array}$ & ND \\
\hline \multirow{3}{*}{ 2-nonanone } & 1 & $\begin{array}{c}6.63 \\
\pm 1.17\end{array}$ & ND & $\begin{array}{c}6.14 \\
\pm 0.36\end{array}$ & $\begin{array}{c}8.20 \\
\pm 1.24\end{array}$ & ND & $\begin{array}{c}8.10 \\
\pm 0.61\end{array}$ & ND \\
\hline & 14 & $\begin{array}{c}5.92 \\
\pm 1.22 \\
\end{array}$ & ND & $\begin{array}{c}5.81 \\
\pm 2.06\end{array}$ & $\begin{array}{c}5.61 \\
\pm 1.03\end{array}$ & ND & $\begin{array}{c}7.27 \\
\pm 0.59\end{array}$ & ND \\
\hline & 28 & $\begin{array}{c}5.53 \\
\pm 0.24\end{array}$ & $\begin{array}{c}7.57 \\
\pm 0.89\end{array}$ & $\begin{array}{c}9.35 \\
\pm 1.06\end{array}$ & $\begin{array}{c}8.39 \\
\pm 0.67\end{array}$ & $\begin{array}{c}7.74 \\
\pm 0.66\end{array}$ & $\begin{array}{r}14.78 \\
\pm 0.95\end{array}$ & $\begin{array}{l}25.86 \\
\pm 0.90 \\
\end{array}$ \\
\hline \multirow{3}{*}{ 4-Octanone } & 1 & $\begin{array}{c}5.60 \\
\pm 0.18 \\
\end{array}$ & $\begin{array}{c}5.57 \\
\pm 0.21 \\
\end{array}$ & $\begin{array}{c}4.72 \\
\pm 0.92 \\
\end{array}$ & $\begin{array}{c}5.19 \\
\pm 0.41 \\
\end{array}$ & $\begin{array}{c}5.43 \\
\pm 0.19 \\
\end{array}$ & $\begin{array}{c}5.01 \\
\pm 1.10\end{array}$ & $\begin{array}{c}5.22 \\
\pm 0.30 \\
\end{array}$ \\
\hline & 14 & $\begin{array}{c}5.89 \\
\pm 0.78 \\
\end{array}$ & $\begin{array}{c}6.12 \\
\pm 0.60 \\
\end{array}$ & $\begin{array}{c}4.83 \\
\pm 0.57 \\
\end{array}$ & $\begin{array}{c}4.96 \\
\pm 0.28 \\
\end{array}$ & $\begin{array}{c}5.11 \\
\pm 0.12 \\
\end{array}$ & $\begin{array}{r}4.94 \\
\pm 1.42 \\
\end{array}$ & $\begin{array}{r}5.90 \\
\pm 0.44 \\
\end{array}$ \\
\hline & 28 & $\begin{array}{c}5.77 \\
\pm 0.17 \\
\end{array}$ & $\begin{array}{r}5.69 \\
\pm 0.32 \\
\end{array}$ & $\begin{array}{c}5.96 \\
\pm 0.00 \\
\end{array}$ & $\begin{array}{c}4.89 \\
\pm 0.21 \\
\end{array}$ & $\begin{array}{c}5.58 \pm \\
0.33 \\
\end{array}$ & $\begin{array}{c}4.99 \pm \\
0.87 \\
\end{array}$ & $\begin{array}{c}5.14 \\
\pm 0.19 \\
\end{array}$ \\
\hline \multirow{3}{*}{$\begin{array}{l}\text { 3-methyl-2- } \\
\text { butanone }\end{array}$} & 1 & ND & ND & ND & $\begin{array}{c}3.63 \\
\pm 0.17\end{array}$ & ND & ND & \\
\hline & 14 & ND & ND & ND & $\begin{array}{c}3.54 \\
\pm 0.35\end{array}$ & ND & ND & $\begin{array}{l}3.38 \\
0.34\end{array}$ \\
\hline & 28 & ND & $\begin{array}{c}2.04 \\
\pm 0.47 \\
\end{array}$ & ND & $\begin{array}{c}4.71 \\
\pm 0.24 \\
\end{array}$ & ND & ND & \\
\hline \multirow{3}{*}{$\begin{array}{l}\text { 2,3-Pentanedione } \\
\text { (Acetylpropionyl) }\end{array}$} & 1 & $\begin{array}{c}3.51 \\
\pm 0.35 \\
\end{array}$ & $\begin{array}{l}11.08 \\
\pm 0.11 \\
\end{array}$ & $\begin{array}{r}13.41 \\
\pm 0.48 \\
\end{array}$ & $\begin{array}{l}25.45 \\
\pm 1.42 \\
\end{array}$ & $\begin{array}{c}3.21 \\
\pm 0.85 \\
\end{array}$ & $\begin{array}{l}20.04 \\
\pm 2.70 \\
\end{array}$ & $\begin{array}{r}24.96 \\
\pm 2.23 \\
\end{array}$ \\
\hline & 14 & $\begin{array}{c}3.38 \\
\pm 0.17 \\
\end{array}$ & $\begin{array}{c}9.77 \\
\pm 0.98\end{array}$ & $\begin{array}{l}22.51 \\
\pm 1.06\end{array}$ & $\begin{array}{l}33.49 \\
\pm 0.57 \\
\end{array}$ & $\begin{array}{c}6.67 \\
\pm 0.34\end{array}$ & $\begin{array}{l}27.22 \\
\pm 3.51 \\
\end{array}$ & $\begin{array}{r}37.40 \\
\pm 2.75 \\
\end{array}$ \\
\hline & 28 & $\begin{array}{c}4.37 \\
\pm 0.30\end{array}$ & $\begin{array}{r}11.00 \\
\pm 1.17\end{array}$ & $\begin{array}{r}15.16 \\
\pm 1.43\end{array}$ & $\begin{array}{l}23.04 \\
\pm 0.43\end{array}$ & $\begin{array}{r}15.00 \\
\pm 0.85\end{array}$ & $\begin{array}{r}17.61 \\
\pm 1.83\end{array}$ & $\begin{array}{r}23.95 \\
\pm 1.72 \\
\end{array}$ \\
\hline \multirow{3}{*}{ 2-Dodecanone } & 1 & $\begin{array}{c}2.39 \\
\pm 0.19 \\
\end{array}$ & ND & ND & ND & ND & ND & $\begin{array}{r}6.30 \\
\pm 0.71 \\
\end{array}$ \\
\hline & 14 & $\begin{array}{c}4.54 \\
\pm 0.66 \\
\end{array}$ & ND & $\begin{array}{c}6.80 \\
\pm 0.27 \\
\end{array}$ & ND & ND & ND & ND \\
\hline & 28 & $\begin{array}{c}6.79 \\
\pm 0.29\end{array}$ & ND & ND & $\begin{array}{l}10.10 \\
\pm 1.24\end{array}$ & ND & ND & ND \\
\hline
\end{tabular}

${ }^{1}$ MSF: whole meal obtained from wheat harvested at milky development stage; ${ }^{2} \mathrm{DSF}$ : whole meal obtained from wheat harvested at milky development stage; ND: not detected 


\section{Sensory characteristic}

Results of sensory evolution of yoghurt samples enriched with MSF and DSF for the 7th and 21st day of storage are given in Table 5. Yoghurt samples enriched with MSF were scored higher than yoghurt with DSF in the evaluation of appearance, and as the contribution rate increased, the likability of the samples decreased in terms of appearance. This outcome is in agreement with data reported by Tomic, Dojnov [33] who investigated the sensory properties of yoghurts enriched with triticale, wheat, and oat fiber $(15 \mathrm{~g} / \mathrm{kg}$ and $30 \mathrm{~g} / \mathrm{kg})$. It was reported that insoluble triticale fiber caused cereal flavor and taste, yellowish-brown color, and a sandy texture in enriched yoghurts. Despite the low-quality ratings given to the yoghurts enriched with $30 \mathrm{~g} / \mathrm{kg}$ fiber due to their grainy texture and a little bitterness, it was reported that the enriched yoghurts were in the 'very good' quality category.

Table 5

Sensory properties of yoghurt sample on the 7 th and 21 st days of storage at $4{ }^{\circ} \mathrm{C}$

\begin{tabular}{|c|c|c|c|c|c|c|c|}
\hline $\begin{array}{c}\text { Period of } \\
\text { storage } \\
\text { (days) }\end{array}$ & Control & $\begin{array}{c}1 \% \\
\text { MSF }\end{array}$ & $\begin{array}{c}2 \% \\
\text { MSF }\end{array}$ & $\begin{array}{c}3 \% \\
\text { MSF }\end{array}$ & $\begin{array}{c}1 \% \\
\text { DSF }\end{array}$ & $\begin{array}{c}2 \% \\
\text { DSF }\end{array}$ & $\begin{array}{c}3 \% \\
\text { DSF }\end{array}$ \\
\hline \multicolumn{8}{|l|}{ Appearance } \\
\hline 7 & $\begin{array}{c}4.77 \pm 0.0 \\
2^{\mathrm{A}, \mathrm{ns}} \\
\end{array}$ & $\begin{array}{c}4.05 \pm 0.5 \\
5^{\mathrm{AB}, \mathrm{ns}}\end{array}$ & $\begin{array}{c}3.70 \\
\pm 0.30^{\mathrm{BC}, \mathrm{ns}} \\
\end{array}$ & $\begin{array}{c}3.12 \\
\pm 0.13^{\mathrm{CD}, \mathrm{ns}} \\
\end{array}$ & $\begin{array}{c}2.88 \\
\pm 0.13^{\mathrm{D}, \mathrm{ns}} \\
\end{array}$ & $\begin{array}{c}3.75 \\
\pm 0.25^{\mathrm{BC}, \mathrm{a}} \\
\end{array}$ & $\begin{array}{c}3.53 \\
\pm 0.28^{\mathrm{BCD}, \mathrm{ns}} \\
\end{array}$ \\
\hline 21 & $\begin{array}{c}4.77 \pm 0.0 \\
1^{\mathrm{A}, \mathrm{ns}} \\
\end{array}$ & $\begin{array}{c}4.10 \pm 0.1 \\
0^{\mathrm{AB}, \mathrm{ns}}\end{array}$ & $\begin{array}{c}3.63 \\
\pm 0.38^{\mathrm{BC}, \mathrm{ns}} \\
\end{array}$ & $\begin{array}{c}3.10 \\
\pm 0.30^{\mathrm{C}, \mathrm{ns}} \\
\end{array}$ & $\begin{array}{c}3.50 \\
\pm 0.50^{\mathrm{BC}, \mathrm{ns}} \\
\end{array}$ & $\begin{array}{c}3.10 \\
\pm 0.10^{\mathrm{C}, \mathrm{b}} \\
\end{array}$ & $\begin{array}{c}3.10 \\
\pm 0.10^{\mathrm{C}, \mathrm{ns}} \\
\end{array}$ \\
\hline \multicolumn{8}{|l|}{ Texture } \\
\hline 7 & \begin{tabular}{|c|}
4.32 \\
$\pm 0.01^{\mathrm{A}, \mathrm{b}}$ \\
\end{tabular} & $\begin{array}{c}3.98 \pm 0.2 \\
3^{\mathrm{AB}, \mathrm{ns}}\end{array}$ & $\begin{array}{c}3.58 \\
\pm 0.18^{\mathrm{AB}, \mathrm{ns}} \\
\end{array}$ & $\begin{array}{c}3.73 \\
\pm 0.53^{\mathrm{AB}, \mathrm{ns}} \\
\end{array}$ & $\begin{array}{c}3.35 \\
\pm 0.15^{\mathrm{B}, \mathrm{b}} \\
\end{array}$ & $\begin{array}{c}4.25 \\
\pm 0.25^{\mathrm{AB}, \mathrm{a}} \\
\end{array}$ & $\begin{array}{c}4.40 \\
\pm 0.60^{\mathrm{A}, \mathrm{ns}} \\
\end{array}$ \\
\hline 21 & \begin{tabular}{|c|}
4.43 \\
$\pm 0.03^{\mathrm{A}, \mathrm{a}}$ \\
\end{tabular} & $\begin{array}{c}4.43 \\
\pm 0.18^{\mathrm{A}, \mathrm{ns}} \\
\end{array}$ & $\begin{array}{c}3.75 \\
\pm 0.25^{\mathrm{BC} \text {,ns }} \\
\end{array}$ & $\begin{array}{c}3.62 \\
\pm 0.38^{\mathrm{BC}, \mathrm{ns}} \\
\end{array}$ & $\begin{array}{c}4.20 \\
\pm 0.20^{\mathrm{AB}, \mathrm{a}} \\
\end{array}$ & $\begin{array}{c}3.43 \\
\pm 0.18^{\mathrm{C}, \mathrm{b}} \\
\end{array}$ & $\begin{array}{c}3.65 \\
\pm 0.15^{\mathrm{BC}, \mathrm{ns}} \\
\end{array}$ \\
\hline \multicolumn{8}{|l|}{ Mouth feel } \\
\hline 7 & $\begin{array}{c}4.45 \\
\pm 0.05^{\mathrm{A}, \mathrm{ns}} \\
\end{array}$ & $\begin{array}{c}3.95 \pm 0.4 \\
5^{\mathrm{AB}, \mathrm{ns}}\end{array}$ & $\begin{array}{c}3.68 \\
\pm 0.08^{\mathrm{B}, \mathrm{ns}} \\
\end{array}$ & $\begin{array}{c}3.35 \\
\pm 0.15^{\mathrm{B}, \mathrm{ns}} \\
\end{array}$ & $\begin{array}{c}3.43 \\
\pm 0.17^{\mathrm{B}, \mathrm{ns}} \\
\end{array}$ & $\begin{array}{c}3.90 \\
\pm 0.10^{\mathrm{AB}, \mathrm{a}} \\
\end{array}$ & $\begin{array}{c}3.60 \\
\pm 0.40^{\mathrm{B}, \mathrm{a}} \\
\end{array}$ \\
\hline 21 & $\begin{array}{c}4.38 \\
\pm 0.03^{\mathrm{A}, \mathrm{ns}} \\
\end{array}$ & $\begin{array}{c}4.15 \\
\pm 0.05^{\mathrm{A}, \mathrm{ns}} \\
\end{array}$ & $\begin{array}{c}3.40 \\
\pm 0.40^{\mathrm{BC}, \mathrm{ns}} \\
\end{array}$ & $\begin{array}{c}3.18 \\
\pm 0.43^{\mathrm{BC}, \mathrm{ns}} \\
\end{array}$ & $\begin{array}{c}3.68 \\
\pm 0.08^{\mathrm{AB}, \mathrm{ns}} \\
\end{array}$ & $\begin{array}{c}3.08 \\
\pm 0.33^{\mathrm{BC}, \mathrm{b}} \\
\end{array}$ & $\begin{array}{c}2.88 \\
\pm 0.13^{\mathrm{C}, \mathrm{b}} \\
\end{array}$ \\
\hline \multicolumn{8}{|l|}{ Odor } \\
\hline 7 & $\begin{array}{c}4.69 \\
\pm 0.01^{\mathrm{A}, \mathrm{ns}} \\
\end{array}$ & \begin{tabular}{c|c|}
4.78 \\
$\pm 0.03^{\mathrm{A}, \mathrm{a}}$ \\
\end{tabular} & $\begin{array}{c}4.65 \\
\pm 0.15^{\text {A,a }} \\
\end{array}$ & $\begin{array}{c}3.88 \\
\pm 0.13^{\mathrm{B}, \mathrm{a}} \\
\end{array}$ & $\begin{array}{c}3.98 \\
\pm 0.23^{\mathrm{B}, \mathrm{ns}} \\
\end{array}$ & $\begin{array}{c}4.10 \\
\pm 0.10^{\mathrm{B}, \mathrm{a}} \\
\end{array}$ & $\begin{array}{c}4.08 \\
\pm 0.33^{\mathrm{B}, \mathrm{a}} \\
\end{array}$ \\
\hline 21 & $\begin{array}{c}4.60 \\
\pm 0.07^{\mathrm{A}, \mathrm{ns}} \\
\end{array}$ & $\begin{array}{c}4.05 \\
\pm 0.05^{\mathrm{AB}, \mathrm{b}} \\
\end{array}$ & $\begin{array}{c}3.30 \\
\pm 0.30^{\mathrm{BC}, \mathrm{b}}\end{array}$ & $\begin{array}{c}3.08 \\
\pm 0.33^{\mathrm{C}, \mathrm{b}} \\
\end{array}$ & $\begin{array}{c}3.53 \\
\pm 0.28^{\mathrm{BC}, \mathrm{ns}} \\
\end{array}$ & $\begin{array}{c}3.05 \\
\pm 0.55^{\mathrm{C}, \mathrm{b}} \\
\end{array}$ & $\begin{array}{c}2.80 \\
\pm 0.20^{\mathrm{C}, \mathrm{b}} \\
\end{array}$ \\
\hline \multicolumn{8}{|l|}{ Taste } \\
\hline 7 & \begin{tabular}{|c|}
4.44 \\
$\pm 0.02^{\mathrm{A}, \mathrm{b}}$ \\
\end{tabular} & \begin{tabular}{|c|}
4.67 \\
$\pm 0.15^{\mathrm{A}, \mathrm{a}}$ \\
\end{tabular} & $\begin{array}{c}4.55 \\
\pm 0.05^{\mathrm{A}, \mathrm{a}} \\
\end{array}$ & $\begin{array}{c}3.45 \\
\pm 0.05^{\mathrm{C}, \mathrm{ns}} \\
\end{array}$ & $\begin{array}{c}3.88 \\
\pm 0.13^{\mathrm{B}, \mathrm{ns}} \\
\end{array}$ & $\begin{array}{c}3.67 \\
\pm 0.08^{\mathrm{BC}, \mathrm{a}} \\
\end{array}$ & $\begin{array}{c}3.57 \\
\pm 0.18^{\mathrm{C}, \mathrm{a}} \\
\end{array}$ \\
\hline 21 & $\begin{array}{c}4.69 \\
\pm 0.01^{\mathrm{A}, \mathrm{a}} \\
\end{array}$ & $\begin{array}{c}4.12 \\
\pm 0.12^{\mathrm{AB}, \mathrm{b}} \\
\end{array}$ & $\begin{array}{c}3.30 \\
\pm 0.20^{\mathrm{CD}, \mathrm{b}} \\
\end{array}$ & $\begin{array}{c}3.02 \\
\pm 0.27^{\mathrm{DE}, \mathrm{ns}} \\
\end{array}$ & $\begin{array}{c}3.77 \\
\pm 0.03^{\mathrm{BC}, \mathrm{ns}} \\
\end{array}$ & $\begin{array}{c}2.72 \\
\pm 0.47^{\mathrm{DE}, \mathrm{b}} \\
\end{array}$ & $\begin{array}{c}2.62 \\
\pm 0.12^{\mathrm{E}, \mathrm{b}} \\
\end{array}$ \\
\hline
\end{tabular}

${ }^{1}$ MSF: whole meal obtained from wheat harvested at milky development stage; ${ }^{2}$ DSF: whole meal obtained from wheat harvested at milky development stage Statistically differences were shown different letters $(\mathrm{P}<0.05)$; ns: not statistically significant.

A-EThe significant differences between the samples were expressed in capital letters, ${ }^{\text {a-b }}$ The significant differences between storage times were expressed in lower case letters. 
Except for yoghurt samples enriched with 2\% DSF that showed lower score in terms of appearance on the 21 st day of storage, there was no statistical difference $(p>0.05)$ depending on the storage period in all other yoghurt samples $(\mathrm{p}>0.05)$. On the 7th day of storage, it was seen that the texture values were not statistically different from each other in enriched yoghurt samples and had lower evaluation scores than control yoghurt. However, it was observed that texture scores decreased on the 21 st day of storage due to the increasing enrichment ratio, which may be due to improved acidity of yoghurts by activities of yoghurt starter cultures leading for syneresis. Increasing of enrichment rate negatively influenced $(\mathrm{p}<0.05)$ the scores for mouth feel due to the higher graininess texture of yoghurts, while the storage period had no effect on the mouth feel. Additionally, the enrichment ratio and storage period significantly $(p<0.05)$ affected in terms of odor and taste. As a result of the sensory evaluation, the least score in terms of these parameters was taken from yoghurt samples enriched with 3\% DSF. As the enrichment ratio increased in yoghurts, the increasingly cereal flavor and taste reduced consumer appreciation. Similar findings are seen in the studies of yoghurt enriched with wheat $[34,35]$. Besides, our sensory evaluation results are supported by Terpou, Bekatorou [15] who produced yoghurt using wheat bran as cell immobilization carrier and evaluated sensory attributes of them. The authors reported that although the highest cereal taste was determined in their yoghurt samples which have a less acidic taste and contain wheat bran in which probiotic cultures were immobilized, they had similar scores with yoghurt samples without wheat bran in terms of smell, appearance, and general acceptability.

\section{Conclusion}

Considering the findings obtained from this study, the use of immature wheat grain flour in the enrichment of yoghurt had led to significant changes in the taste and aroma compounds of yoghurt. A reduction in the amount of acetaldehyde, which is an important carbonyl compound for yoghurt taste and aroma, was observed with increasing concentrations of MSGF and DSGF. Also, it could be stated that isobutyl 2-methylvalerate determined in yoghurt samples enriched with MSF and DSF caused cereal flavor and taste in the final product, and this taste intensified with increasing enrichment ratios. Except for control yoghurt, \%1 MSF yoghurt samples received the best sensory scores and gained the highest appreciation from consumers. As the concentration of MSF and DSF increased in yoghurt formulation, the cereal taste increased and this reduced the overall acceptability. For these reasons, further studies can be carried out by using various flavoring agents to reduce the aroma and flavor defects that occur in yoghurts.

Acknowledgements. This experimental data was obtained from the doctoral dissertation and it was supported by Selcuk University Scientific Research Projects Coordinatorship (Grant number, 14101005).

\section{References}

1. Innocente N., Biasutti M., Rita F., Brichese R., Comi G., Iacumin L. (2016), Effect of Indigenous Lactobacillus rhamnosus Isolated from Bovine Milk on Microbiological 
Characteristics and Aromatic Profile of Traditional Yogurt, LWT-Food Science and Technology, 66, pp. 158-164.

2. Law B.A. (1981), The Formation of Aroma and Flovour Compunds in Fermented Dairy Product, Dairy Science Abstract, 43, pp. 143-154.

3. Ott A., Fay L.B., Chaintreau A. (1997), Determination and Origin of the Aroma Impact Compounds of Yogurt Flavor, Journal of Agricultural and Food Chemistry,45(3), pp. 850858.

4. Tamime A.Y., Robinson R.K. (2007), Yoghurt: Science and Technology. 3rd edition ed, Woodhead Publishing.

5. Lees G.J., Jago G.R. (1976), Formation of Acetaldehyde from Threonine by Lactic Acid Bacteria, Journal of Dairy Research,43(1), pp. 75-83.

6. Chau C.F., Huang Y.L. (2003), Comparison of the Chemical Composition and Physicochemical Properties of Different Fibers Prepared from the Peel of Citrus Sinensis L. Cv. Liucheng, Journal Agr. Food Chem, 51(9), pp. 2615-2618.

7. Casiraghi M.C., Pagani M.A., Erba D., Marti A., Cecchini C., D'egidio M.G. (2013), Quality and Nutritional Properties of Pasta Products Enriched with Immature Wheat Grain, International Journal of Food Sciences and Nutrition, 64(5), pp. 631-637.

8. Pepe O., Ventorino V., Cavella S., Fagnano M., Brugno R. (2013), Prebiotic Content of Bread Prepared with Flour from Immature Wheat Grain and Selected Dextran-Producing Lactic Acid Bacteria, Applied and Environmental Microbiology, 79(12), pp. 3779-3785.

9. Kim J.K., Kim S.K. (2016), Antioxidant and Antiproliferative Activities in Immature and Mature Wheat Kernels, Food Chem, 196, pp. 638-645.

10. Decourcelle N., Lubbers S., Vallet N., Rondeau P., Guichard E. (2004), Effect of Thickeners and Sweeteners on the Release of Blended Aroma Compounds in Fat-Free Stirred Yoghurt During Shear Conditions, International Dairy Journal, 14(9), pp. 783-789.

11. Popa D., Ustunol Z. (2011), Sensory Attributes of Low-Fat Strawberry Yoghurt as Influenced by Honey from Different Floral Sources, Sucrose and High-Fructose Corn Sweetener, International Journal of Dairy Technology,64(3), pp. 451-454.

12. Lee J.H., Diono R., Kim G.Y., Mind D.B. (2003), Optimization of Solid Phase Microextraction Analysis for the Headspace Volatile Compounds of Parmesan Cheese, Journal of Agricultural and Food Chemistry, 51(5), pp. 1136-1140.

13. Tamime,A.Y., Barrantes,E., Sword A.M. (1996), The Effect of Starch Based Fat Substitutes on the Microstructure of Set-Style Yogurt Made from Reconstituted Skimmed Milk Powder, International Journal of Dairy Technology, 49(1), pp. 1-10.

14. Minitab C. (1991), Minitab Reference Manual (Release 7.1), State Coll.

15. Terpou A., Bekatorou A., Kanellaki M., Koutinas A.A., Nigam P. (2017), Enhanced Probiotic Viability and Aromatic Profile of Yogurts Produced Using Wheat Bran (Triticum Aestivum) as Cell Immobilization Carrier, Process Biochemistry, 55, pp. 1-10.

16. Fernández-García E., McGregor J.U., Traylor S. (1998), The Addition of Oat Fiber and Natural Alternative Sweeteners in the Manufacture of Plain Yogurt, Journal of Dairy Science, 81(3), pp. 655-663.

17. Donkor O.N., Nilmini S.L.I., Stolic P., Vasiljevic T., Shah N.P. (2007), Survival and Activity of Selected Probiotic Organisms in Set-Type Yoghurt During Cold Storage, International Dairy Journal, 17, pp. 657-665.

18. Terpou A., Gialleli A., Bekatorou A., Dimitrellou D., Ganatsios V., Barouni E., Koutinas A.A., Kanellaki M. (2017), Sour Milk Production by Wheat Bran Supported Probiotic Biocatalyst as Starter Culture, Food and Bioproducts Processing, 101, pp. 184-192.

19. Curioni P.M.G., Bosset J.O. (2002), Key Odorants in Various Cheese Types as Determined by Gas Chromatography-Olfactometry, International Dairy Journal, 12(12), pp. 959-984. 
20. Merendino N., D'Aquino M., Molinaria R., De Gara L., D'Egidio M.G., Paradiso A., Cecchini C., Corradini C., Tomassi G. (2006), Chemical Characterization and Biological Effects of Immature Durum Wheat in Rats, Journal of Cereal Science, 43(2), pp. 129-136.

21. Ritsema T., Smeekensy S. (2003), Fructans: Beneficial for Plants and Humans. Current Opinion in Plant Biology, 6, pp. 223-230.

22. Tamime A.Y., Deeth H.C. (1980), Yogurt: Technology and Biochemistry. Journal of Food Protection, 43(12), pp. 939-977.

23. Beshkova D., Simova E., Frengova G., Simov Z. (1988), Production of Flavour Compounds by Yogurt Starter Cultures, Journal of Microbiology and Biotechnology, 20, pp. 180-184.

24. Georgala A.I.K., Tsakalidou E., Kandarakis I., Kalantzopoulos G. (1995), Flavour Production in Ewe's Milk and Ewe's Milk Yogurt, by Single Strains and Combinations of Streptococcus thermophilus and Lactobacillus delbrueckii subsp. bulgaricus, Isolated from Traditional Greek Yoghurt, Le Lait,75, pp. 271-279.

25. Akın N. (1994), Filtration Methods for Making Turkish Süzme (Thick) Yogurt. (A doctoral thesis), Loughborough University of Thecnology, Loughborough.

26. Güler Z., Taşdelen A., Şenol H., Kerimoğlu N., Temel U. (2009), The Determination of Volatile Compounds in Set Type Yogurts Using Static Headspace Gas Chromatographic Method, Glda, 34(3), pp. 137-142.

27. Hassan F.A.M., Samira S.M., Enab A.K. (2001), Preparation of Dairy Products Enriched with Sea Same Seed Protein, Egypt. J. Food Sci., 29, pp. 79-93.

28. Hussein M.M., Hassan F.A.M., Daym H.H., Salama A., Enab A.K., Abd El-Galil A.A. (2011), Utilization of Some Plant Polysaccharides for Improving Yoghurt Consistency, Annals of Agricultural Science, 56(2), pp. 97-103.

29. Demirci T., Öztürk Negiş H.İ., Oraç A., Konak Göktepe Ç., Sözeri Atik D., Aktaş K., Demirci S., Sert D., Akın N. (2019), Immature Wheat Grain as a Potential Prebiotic Ingredient in Set-Type Yoghurts: Impact on Antioxidative, Textural Properties and Survival of Different Probiotics, Journal of Food Science and Technology, 56(12), pp. 5474-5483.

30. Özer B.H. (2006), Yoğurt Biyokimyası, in Yoğurt Bilimi ve Teknolojisi, Sidas Yayınları, pp. 488.

31. Steele D.H., Thornburg, M.J., Stanley, J.S., Miller, R.R., Brooke, R., Cushman, J.R., Cruzan, G. (1994), Determination of Styrene in Selected Foods, Journal of Agricultural and Food Chemistry, 42(8), pp. 1661-1665.

32. Kaminarides S., Stamou P., Massouras T. (2007), Comparison of the Characteristics Ofset Type Yoghurt Made from Ovine Milk of Different Fat Content, International Journal of Food Science \& Technology,42(9), pp. 1019-1028.

33. Tomic N., Dojnov B., Miocinovic J., Tomasevic I., Smigic N., Djekic I., Vujcic Z. (2017), Enrichment of Yoghurt with Insoluble Dietary Fiber from Triticale - a Sensory Perspective, LWT - Food Science and Technology, 80, pp. 59-66.

34. Seçkin K.A., Baladura E. (2012), Effect of Using Some Dietary Fibers on Color, Texture and Sensory Properties of Strained Yogurt, Gida, 37(2), pp. 63-69.

35. Coman M.M., Verdenelli M.C., Cecchini C., Silvi S., Vasile A., Bahrim G.E., Orpianesi C., Cresci A. (2013), Effect of Buckwheat Flour and Oat Bran on Growth and Cell Viability of the Probiotic Strains Lactobacillus Rhamnosus IMC 501 ${ }^{\circledR}$, Lactobacillus paracasei IMC $502^{\circledR}$ and Their Combination Synbio ${ }^{\circledR}$, in Synbiotic Fermented Milk, International Journal of Food Microbiology, 167(2), pp. 261-268. 